\title{
EARLY DEVELOPMENT OF TWO HELPER T CELL SUBSETS FOR DELAYED HYPERSENSITIVITY AFTER BONE MARROW TRANSPLANTATION
}

\author{
Ikuo Kawamura ${ }^{1}$, Kunisuke Himeno, Misao Sakumoto, Masatoshi Eto and Kikuo \\ Nомото \\ Department of Immunology, Medical Institute of Bioregulation, Kyushu University 69, Maidashi, \\ Higashiku, Fukuoka 812, Japan
}

\begin{abstract}
Murine delayed hypersensitivity (DTH) was induced by the cooperation of two subsets of $T$ cells. One of these subsets $\left(\mathrm{T}_{\text {prod }}\right)$ produces the antigen-specific DTH augmentation factor (DAF). The other $\left(T_{\text {acc }}\right)$ receives DAF which is needed for the induction of DTH by antigen stimulation. These two types of T cells require the presence of the thymus only for a short term in their differentiation. In this paper, bone marrow cells were transferred to irradiated syngeneic mice and the rapid recovery of the functions of $T_{\text {prod }}$ and $T_{\text {acc }}$ were investigated suggesting a low degree of thymus-dependency in their development. When the reconstituted mice were immunized 2 weeks after bone marrow transplantation, the degree of delayed footpad reaction elicited 1 week later recovered to the same level as that in immunized normal mice. The functions of both $\mathrm{T}_{\text {prod }}$ and $\mathrm{T}_{\mathrm{acc}}$ also recovered to the normal levels within such a period. The recovery of $T_{a c c}$ appeared to occur about 1 week earlier than that of $\mathrm{T}_{\text {prod }}$. Furthermore, DAF was fractionated from the sera of mice immunized with chicken erythrocytes (CRBC) by DEAE chromatography and tested for binding to solubilized CRBC antigens. The DAF molecule had a molecular weight of $150-170 \mathrm{~K}$ as shown by blotting analysis.
\end{abstract}

Delayed hypersensitivity (DTH) is positively regulated by helper $\mathrm{T}$ cells when $\mathrm{T}$ cells recognize protein antigens in association with class II MHC determinants on antigen-presenting cells. These helper $\mathrm{T}$ cells express Lyt1 and L3T4 antigens but not Lyt 2 antigen. Recently

\footnotetext{
${ }^{1}$ Present address: Department of Bacteriology, School of Medicine, Niigata University, 757 Ichibancho, Asahimachidouri, Niigata 951, Japan Abbreviations: DAF, delayed hypersensitivity augmentation factor; DTH, delayed hypersensitivity; $\mathrm{T}_{\text {prod }}, \mathrm{DAF}$ producer $\mathrm{T}$ cell; $\mathrm{T}_{\text {acc }}, \mathrm{DAF}$ acceptor $\mathrm{T}$ cell; CRBC, chicken erythrocytes; HPLC, high performance liquid chromatography
}

several papers have shown that murine helper $\mathrm{T}$ cells can be devided into two subsets which are distinguished by their patterns of lymphokine secretion $(17,2,3)$ or some functional criteria $(28,27,7,16,11)$. In previous studies, we have demonstrated that helper $\mathrm{T}$ cells are ontogenically heterologous and there are differences in thymus-dependency in their development or differentiation $(25,24,8-10,20)$. In fact, DTH to xenogeneic erythrocytes and protection against an infection of Listeria monocytogenes were induced at normal levels in mice thymectomized neonatally within 1 day after birth, while antigen-specific helper, suppressor and killer activities or tuberculin- 
type DTH did not appear. These T cells in the thymectomized mice may require little proliferation to express their functions because such $\mathrm{T}$ cells weakly respond to mitogenic lectins $(25,20)$ and are resistant to treatment with irradiation $(21,12,29)$ and cyclophosphamide $(25,24,26,6)$. Furthermore, DTH to xenogeneic erythrocytes and protective immunity to an infection of Listeria monocytogenes developed earlier than the other $\mathrm{T}$ cell responses in the mice irradiated and reconstituted with syngeneic bone marrow cells (23).

In addition, murine DTH is controlled by a cooperation of two subsets of $\mathrm{T}$ cells which is mediated by DAF $(31,32,6,19,18,33)$. One $T$ cell subset, provisionally termed producer $\mathrm{T}$ cell $\left(\mathrm{T}_{\text {prod }}\right)$, secretes DAF and the other $\mathrm{T}$ cell subset $\left(\mathrm{L}_{3} \mathrm{~T}^{+}, \mathrm{Lyt}^{-}{ }^{-}\right)$called acceptor $\mathrm{T}$ cell $\left(\mathrm{T}_{\mathrm{acc}}\right)$, receives DAF with a restriction of immunoglobulin heavy chain locus-linked gene and is needed for the induction of DTH after antigen stimulation (34). In this system, DAF allow the expansion of antigen-specific $\mathrm{T}$ cells, by a mechanism not involving the proliferation of the antigen-specific $\mathrm{T}$ cell clones. Thus immune competent $T$ cells capable of inducing DTH are quickly recruited after antigen stimulation. We have tentatively termed the immune response associated with such $T$ cells as 'the primitive $T$ cell response'.

This study investigates the periods of reconstitutions of $\mathrm{T}_{\text {prod }}$ and $\mathrm{T}_{\text {acc }}$ involved in primitive $T$ cell response after syngeneic bone marrow transplantation. $T_{\text {prod }}$ was reconstituted within 3 weeks after the transplantation and the function of $\mathrm{T}_{\text {acc }}$ was restored within 2 weeks. The DAF molecule had a molecular weight of $150-170 \mathrm{~K}$.

\section{MATERIALS AND METHODS}

Mice

Female $\mathrm{C} 3 \mathrm{H} / \mathrm{He}$ mice at 7 to 9 weeks of age were purchased from Shizuoka Laboratory Animal Center (Hamamatsu, Japan) and kept for a week before use.

\section{Antigen}

Chicken erythrocytes (CRBC) were obtained by a cardiac puncture from normal hens and washed three times with phosphate-buffered saline (PBS). To prepare ${ }^{125}$ I-labeled mem- brane antigens, CRBC was suspended in a hypotonic solution of $10 \mathrm{mM}$ phosphate buffer ( $\mathrm{pH} 7.2$ ) with $10 \mu \mathrm{g} / \mathrm{ml}$ DNase I (Sigma, St. Louis, MO) at $37^{\circ} \mathrm{C}$ for $30 \mathrm{~min}$ and centrifuged at 3,000 rpm for $5 \mathrm{~min}$. The precipitate was washed three times with PBS and labeled with $500 \mu \mathrm{Ci}$ of $\mathrm{Na}^{125} \mathrm{I}$ (Amersham, Buckinghamshire, England) using Iodogen (Piece Chemical, Rockford, IL) (13). The preparation was resuspended in $10 \mathrm{mM}$ phosphate buffer with 1\% Nonidet P-40 (Sigma) in order to solubilize the protein antigens of the CRBC membranes and then separated from free iodine on Sephadex G-25 column. The radioactive fractions were pooled and then used as a probe in binding analysis to detect DAF molecules.

\section{Bone Marrow Transplantation}

Bone marrow cells from $\mathrm{C} 3 \mathrm{H} / \mathrm{He}$ mice were routinely treated with Thy 1.2 antibody (F7D5, Serotec, Oxford, England) and complement (Cedarlane, Ontario, Canada). After washing three times with RPMI 1640 medium, the bone marrow cells $\left(5 \times 10^{6}\right)$ were transferred to syngeneic mice which had been lethally irradiated ( 950 rads) $24 \mathrm{~h}$ beforehand.

\section{Induction of DTH and Preparation of Immune Serum}

Mice were intraperitoneally treated with cyclophosphamide (Shionogi, Osaka, Japan; 50$100 \mathrm{mg} / \mathrm{kg}$ ) 2 days previously or left untreated and immunized subcutaneously with $1 \times 10^{8}$ CRBC emulsified with complete Freund's adjuvant (Difco Lab., Detroit, MI) supplemented with $5 \mathrm{mg} / \mathrm{ml}$ heat-killed Mycobacterium tuberculosis Aoyama B. Seven days after immunization, $2.5 \times 10^{7} \mathrm{CRBC}$ in saline were injected into the left hind footpad of each mouse. Twenty-four hours later, the degrees of footpad swelling were measured and expressed as the difference in the thickness between the left and right footpad. Further, blood was taken afterwards and used as the source of immune serum.

\section{Assay for the Activity of DAF by Delayed Footpad Reaction}

DAF activity was evaluated by the degree of 
delayed footpad reaction. Mice were intraperitoneally injected with cyclophosphamide (50$100 \mathrm{mg} / \mathrm{kg}$ ) 4 days beforehand or left untreated and then given intravenously $1 \mathrm{ml}$ of immune serum or purified fractions. Six hours later, the mice were immunized with $2.5 \times 10^{6}$ CRBC in saline into the right hind footpad. For measuring the appearance of $\mathrm{T}_{\mathrm{acc}}, 2.5 \times 10^{7}$ CRBC in saline were injected to immunize firmly the recipients. Three days after the immunization, delayed footpad reaction was elicited by an injection of $2.5 \times 10^{7} \mathrm{CRBC}$ in saline into the left hind footpad and the footpad swelling was measured $24 \mathrm{~h}$ later. The results are shown as the mean \pm the standard deviation of the five mice.

\section{Assay for the Appearance of DAF Producer $T$ Cells $\left(T_{\text {prod }}\right)$}

To observe the appearance of $\mathrm{T}_{\text {prod }}$, DTH was induced in the reconstituted mice 1,2 or 3 weeks after bone marrow transplantation. In the cyclophosphamide-treated group, mice were intraperitoneally injected with cyclophosphamide $(50 \mathrm{mg} / \mathrm{kg}) 1,2$ or 3 weeks after the transplantation and immunized with CRBC in complete Freund's adjuvant 2 days later. In cyclophosphamide-nontreated group, mice were first immunized with CRBC in complete Freund's adjuvant at the same time as the cyclophosphamide-treated groups tested $(9,16$ or 23 days after bone marrow transplantation). Both groups were tested for delayed footpad reaction 1 week later. After the measurement of the footpad swelling to determine the recovery of DTH in the reconstituted mice, the sera were prepared and DAF activity in the sera was measured. For convenience, the groups used here and elsewhere at 1,2 or 3 weeks after bone marrow transplantation were described as a 1-week group, a 2week group and a 3-week group.

\section{Assay for the Appearance of DAF Acceptor $T$ Cells $\left(T_{\text {acc }}\right)$}

To determine the appearance of $T_{\text {acc }}$, the assay for DAF activity was performed using an immune serum with DAF activity and the reconstituted mice as recipients. In the cyclophosphamide-treated group, the recipients were intraperitoneally injected with cyclo- phosphamide $(50 \mathrm{mg} / \mathrm{kg})$ 1, 2 or 3 weeks after bone marrow transplantation. These mice were transferred with immune serum 4 days later and immunized with $\mathrm{CRBC} 6 \mathrm{~h}$ after the serum transfer. In the cyclophosphamidenontreated group, mice were transferred with immune serum and immunized with CRBC at the same time as cyclophosphamide-treated groups (actually 11,18 or 25 days after bone marrow transplantation). Both groups were tested for delayed footpad reaction 3 days after immunization.

\section{Purification of DAF from Immune Serum}

The immune serum was treated with $50 \%$ (v/ v) saturated ammonium sulfate solution and centrifuged at 7,500 rpm for $20 \mathrm{~min}$ to collect the precipitate. After repeating two cycles of this procedure, the preparation dissolved in $10 \mathrm{mM}$ phosphate buffer ( $\mathrm{pH}$ 7.2) was applied to a DEAE high performance liquid chromatography (HPLC) column and eluted by a linear gradient of $\mathrm{NaCl}$ concentration $(0-1 \mathrm{M})$ at a flow rate of $1 \mathrm{ml} / \mathrm{min}$. The $2.5 \mathrm{~min}$ fractions were then tested for DAF activity.

\section{Identification of $D A F$}

DAF was identified by a modified Western blotting method using ${ }^{125}$ I-labeled CRBC antigens. Briefly, the fractions containing DAF activity semi-purified by DEAE-HPLC column were electrophoresed on a $7.5 \%$ polyacrylamide gel at $10 \mathrm{~mA}$ for $6-9 \mathrm{~h}$ and sequentially transferred to nitorocellulose membrane (Schleicher and Schuell, F.R.G.) in electrode buffer (Tris: $5 \mathrm{mM}$, glycine: $38.4 \mathrm{mM}$, pH 8.3) at $30 \mathrm{~V}$ overnight. The membrane was incubated with ${ }^{125}$ I-labeled $\mathrm{CRBC}$ antigens in $10 \mathrm{mM}$ phosphate buffer ( $\mathrm{pH}$ 7.2) containing $3 \%$ bovine serum albumin (Sigma) and $1 \%$ polyoxyethylene $(20)$ sorbitan monolaurate (Tween 20; Wako Pure Chemical, Osaka, Japan) at room temperature for $2 \mathrm{~h}$. After incubation, the membrane was washed with 10 $\mathrm{mM}$ phosphate buffer containing 1\% Tween 20 , dried up and then exposed at $-70^{\circ} \mathrm{C}$ to $\mathrm{X}$ ray film using an intensifying screen.

\section{Statistics}

The statistical significance of the data was 


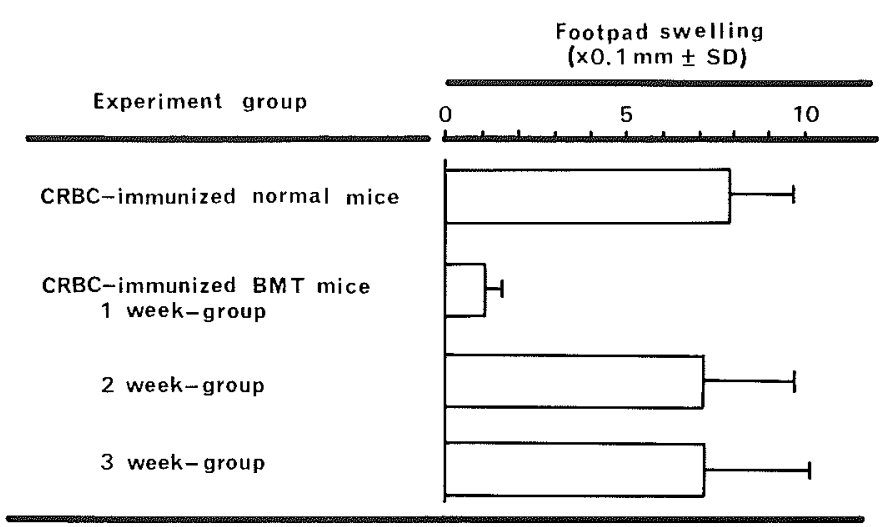

Fig. 1 Recovery of delayed footpad reaction after bone marrow transplantation. Reconstituted $\mathrm{C} 3 \mathrm{H}$ mice with syngeneic bone marrow cells (BMT mice) were immunized with $1 \times 10^{8} \mathrm{CRBC}$ in complete Freund's adjuvant 1, 2 or 3 weeks after bone marrow transplantation. Seven days after immunization, these mice were injected into the hind footpad with $2.5 \times 10^{7} \mathrm{CRBC}$ in saline. One day later, the footpad swelling was measured. Groups that were immunized with CRBC in complete Freund's adjuvant 1, 2 or 3 weeks after bone marrow transplantation were respectively expressed as the 1-week group, 2-week group and 3-week group, respectively.

determined by Student's $t$ test. A $P$ value of less than 0.05 was taken as significant.

\section{RESULTS}

\section{Appearance of Delayed Hypersensitivity Induced by CRBC after Bone Marrow Transplantation}

First, the time for the recovery of delayed footpad reaction in the reconstituted hosts was determined. $\mathrm{C} 3 \mathrm{H} / \mathrm{He}$ mice irradiated and transplanted with syngeneic bone marrow cells were immunized with CRBC in complete Freund's adjuvant 1,2 or 3 weeks after bone marrow transplantation. Seven days after the immunization, the mice were injected with CRBC into the footpad and the specific swelling of the footpad was measured. As shown in Fig. 1, the 1-week group did not show positive delayed footpad reaction. However, the 2- and 3 -week groups showed a positive reaction comparable to that of immunized normal control.

Recovery of DAF Producer $T$ Cells $\left(T_{\text {prod }}\right)$ after Bone Marrow Transplantation

We have observed that DAF occurs in the serum of normal mice following immunization. In this study, the period of recovery of $\mathrm{T}_{\text {prod }}$ activity was determined by measuring DAF activity in the serum of the reconstituted mice. Sera prepared from the 1-week group with or without cyclophosphamide treatment showed virtually no DAF activity (Table 1 ). On the other hand, sera prepared from the 2and 3-week groups showed DAF activity and the activity in the serum of the 3-week group with cyclophosphamide treatment was as high as that in the serum of immunized normal mice.

Recovery of DAF Acceptor T Cells $\left(T_{\text {acc }}\right)$ after Bone Marrow Transplantation

We previously showed that DAF required $\mathrm{T}_{\text {acc }}$ to induce DTH (18). $\mathrm{T}_{\text {acc }}$, as well as $\mathrm{T}_{\text {prod, }}$, showed a low degree of thymus-dependency (6) and was phenotypically $\mathrm{L} 3 \mathrm{~T}^{+}$and $\mathrm{Lyt} 2^{-}$ (34). In this experiment, we observed the recovery of $\mathrm{T}_{\text {acc }}$ activity after bone marrow transplantation. As shown in Table 2, $\mathrm{T}_{\text {acc }}$ activity was already detectable in the 1 -week group. The data showed $\mathrm{T}_{\text {acc }}$ activity quickly recovered and the recovery of $T_{\text {prod }}$ may require about 1 week longer than that of $\mathrm{T}_{\mathrm{acc}}$. 
Table 1 Recovery of $T_{\text {prod }}$ after Bone Marrow Transplantation

\begin{tabular}{lcc}
\hline \multicolumn{1}{c}{ Serum donor } & \multicolumn{2}{c}{ Footpad swelling $(\times 0.1 \mathrm{~mm})$} \\
\cline { 2 - 3 } & Experiment 1 & Experiment 2 \\
\hline Non-transferred control & $0.4 \pm 0.6$ & $0.6 \pm 0.3$ \\
CRBC-immunized normal mice & $4.6 \pm 0.9^{\mathrm{e}}$ & $2.7 \pm 1.1^{\mathrm{c}}$ \\
CRBC-immunized BMT mice & & \\
1-week group & $1.5 \pm 1.3$ & $0.5 \pm 0.4$ \\
2-week group & $2.1 \pm 0.8^{\mathrm{c}}$ & $1.7 \pm 0.1^{\mathrm{d}}$ \\
3-week group & $4.5 \pm 0.8^{\mathrm{e}}$ & - \\
\hline
\end{tabular}

${ }^{a}$ Reconstituted C3H mice (BMT mice) were treated (Experiment 1) or not treated with cyclophosphamide (Experiment 2) 1, 2 or 3 weeks after irradiation and bone marrow transplantation. These mice were immunized with CRBC in complete Freund's adjuvant 2 days after treatment and injected for elicitation with $\mathrm{CRBC}$ in saline 7 days after immunization. Sera were obtained $24 \mathrm{~h}$ after the elicitation to examine DAF activity. ${ }^{b}$ Groups were designated as described in Materials and Methods. 'Significantly different from non-transferred control, $P<0.05$. ${ }^{\mathrm{d}} P<0.005$. ${ }^{\mathrm{e}} P<0.001$

Table 2 Recovery of $T_{\text {acc }}$ after Bone Marrow Transplantation ${ }^{a}$

\begin{tabular}{clccc}
\hline \multirow{2}{*}{ Experiment } & \multirow{2}{*}{ Transferred serum } & \multicolumn{3}{c}{ Footpad swelling $(\times 0.1 \mathrm{~mm})$} \\
\cline { 3 - 5 } & & 1-week group $^{\mathrm{b}}$ & 2-week group & 3-week group \\
\hline 1 & Nontreated control & $0.6 \pm 0.6$ & $0.9 \pm 0.6$ & $1.3 \pm 0.9$ \\
\multirow{2}{*}{2} & CRBC-immunized & $1.7 \pm 0.4^{\mathrm{f}}$ & $2.0 \pm 0.4^{\mathrm{c}}$ & $2.8 \pm 1.0^{\mathrm{d}}$ \\
& Nontreated control & $0.1 \pm 0.1$ & $0.7 \pm 0.4$ & - \\
& CRBC-immunized & $1.3 \pm 0.2^{\mathrm{e}}$ & $2.8 \pm 0.7^{\mathrm{e}}$ & - \\
\hline
\end{tabular}

${ }^{\mathrm{a}} \mathrm{C} 3 \mathrm{H}$ mice were treated (Experiment 1) or not treated with cyclophosphamide (Experiment 2) 1, 2 or 3 weeks after irradiation and bone marrow transplantation. These mice were transferred with immune serum 4 days after the treatment and immunized with $2.5 \times 10^{7} \mathrm{CRBC}$ in saline $6 \mathrm{~h}$ after the serum transfer. CRBC in saline were injected into a hind footpad for elicitation 3 days after the immunization and footpad swelling was measured $24 \mathrm{~h}$ after the elicita-

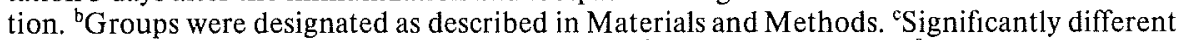
from normal-serum transferred group, $P<0.05$. ${ }^{\mathrm{d}} P<0.01$. ${ }^{\mathrm{e}} P<0.005$. ${ }^{\mathrm{f}} P<0.001$

\section{Purification and Identification of DAF Molecule}

The following experiment describes the partial purification of DAF molecules. Precipitates from immune serum by $50 \%$ saturation of ammonium sulfate were first fractionated by DEAE-HPLC column and individual fractions were assayed for DAF activity. Fig. 2 shows that DAF activity from the immune serum was eluted at $0.1-0.2 \mathrm{M} \mathrm{NaCl}$. We then identified the DAF molecules by a modified Western blotting method using ${ }^{125}$ I-labeled CRBC antigens as a probe. The positive fractions for DAF activity separated by DEAEHPLC column were analyzed by polyacryl- amide gel electrophoresis and autoradiography. As shown in Fig. 3, a molecule at 150-170 K reacted with $\mathrm{CRBC}$ antigens. No other bands reacted with the probe. It was observed that proteins in normal serum and in the serum immunized with sheep erythrocytes did not react with the CRBC antigens (data not shown).

\section{DISCUSSION}

In this study, delayed footpad reaction became detectable when the transplanted mice were immunized with CRBC 2 weeks after bone marrow transplantation. The results show that both $T_{\text {prod }}$ and $T_{\text {acc }}$ recover rapidly after the 

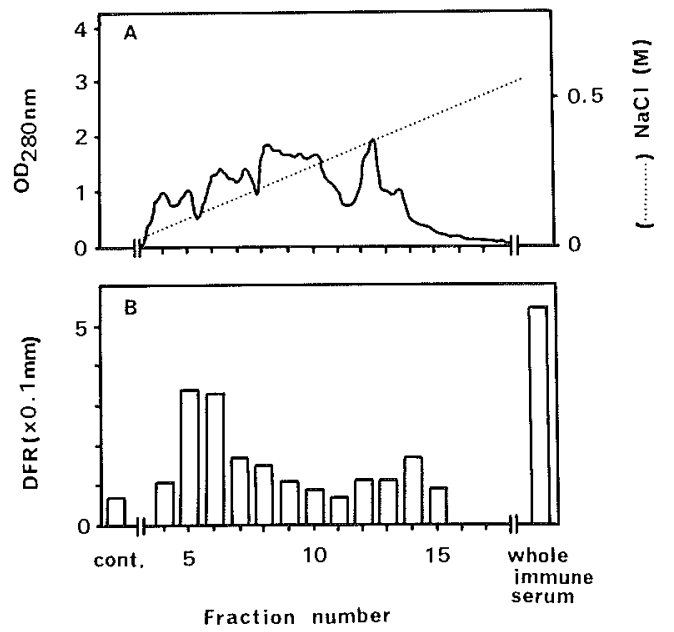

Fig, 2 Purification of DAF molecule from CRBCimmune serum. A: Serum from mice immunized with CRBC was applied to a DEAE-HPLC column and eluted by a linear gradient of $\mathrm{NaCl}$ concentration $(0.8 \mathrm{M} / \mathrm{h})$ at a flow rate of $1 \mathrm{ml} / \mathrm{min}$. B: The $2.5 \mathrm{~min}$ fractions were assayed for DAF activity by delayed footpad reaction (DFR) as described in Materials and Methods.

transplantation, though the time course of their recovery was not identical. At 1-3 weeks, the spleens in mice transplanted with bone marrow cells contained a small proportion of Thy- $1^{+}$cells (below 2.5\%) (23). However, $\mathrm{T}$ cell subsets capable of inducing DTH existed in the spleen because DTH was produced by the footpad transfer of the sensitized spleen cells from these mice together with the antigens. Moreover, the splenic $\mathrm{T}$ cells hardly expressed any $\beta$ chain messenger RNA of $\mathrm{T}$ cell antigen receptor but significantly expressed $\gamma$ chain messages (23). There is a possibility that $T_{\text {prod }}$ and $T_{\text {acc }}$ may use TcR- $\gamma$ as their antigen receptors.

Recently, Mosmann et al. (17) have demonstrated that helper $\mathrm{T}$ cell clones could be subdivided into at least two subtypes: $\mathrm{TH} 1$ and TH2. They showed that TH1 clone produced interleukin 2 and interferon $\gamma$, and generated DTH and cytotoxic $\mathrm{T}$ cells but $\mathrm{TH} 2$ clone produced interleukin 4 and interleukin 5 , and augmented antibody secretion. We have demonstrated that the subsets of helper $\mathrm{T}$ cells were different in the thymus-dependency of their differentiation. Helper $T$ cells for DTH showed a low degree of thymus-

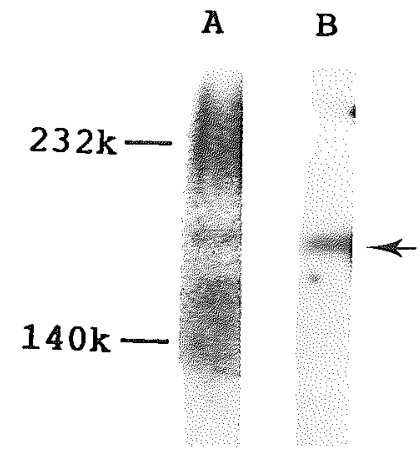

Fig. 3 Identification of DAF molecule. Fractions containing DAF activity from the DEAE-HPLC column were electrophoresed on polyacrylamide gel under non-reducing condition and subjected to modifted Western blotting method using ${ }^{125} \mathrm{I}$ labeled CRBC antigens as a probe. A: Coomassie blue-stained pattern of the gel. B: The arrow indicates the reactive band to ${ }^{125}$ I-labeled CRBC antigens.

dependency, but those for antibody production showed a high degree. Furthermore, Kurt-Jones et al. (14) have indicated that TH1 clones proliferate only in response to interleukin 2 and their growth is not affected by interleukin 1. We and Tucker and Bretscher (30) have observed that the function of helper T cells for DTH is resistant to treatment with irradiation or cyclophosphamide. From these results, $T_{\text {prod }}$ and $T_{\text {acc }}$ in primitive $T$ cell response might require either less proliferation, or none at all, to exert the function. Although this phenomena may apparently reflect the intrinsic properties of such T cells, we have not definitively established this fact as yet, and that is a subject of further investigation.

From previous studies, the mechanism whereby DAF augments delayed footpad reaction may be by binding to non-sensitized $T_{\text {acc }}$ and causing them to acquire antigen specificity. The alternative view is that DAF passively favours an increase of antigen specific $\mathrm{T}$ cell clones. DAF had an antigen binding activity and was shown to bind the specific antigen which was used for in vivo immunization. In this experiment, DAF was separated from the 
immune serum by using DEAE-HPLC column and identified by a modified Western blotting method using the binding ability of DAF to the specific antigen. As shown in Fig. 3, only molecules of $150-170 \mathrm{~K}$ reacted with CRBC antigens. The data suggested this molecule was either DAF or the antigen binding part of DAF. It was unlikely to be immunoglobulins because the serum of mice immunized with CRBC contained only a small amount of CRBC specific immunoglobulins (6) and the DAF activity was not absorbed by anti-mouse Ig column $(32,18,33)$.

Some investigators demonstrated antigenspecific or antigen-binding $\mathrm{T}$ cell helper factors in delayed type $(4,5,15)$ or immediate type hypersensitivity $(22,1)$. However, there are some differences from DAF with respect to molecular weights, expression mechanisms or inductive conditions of each factor. To elucidate the precise mechanism of primitive $T$ cell response, we have to characterize DAF molecule biochemically and genetically, and establish $\mathrm{T}$ cell clones or $\mathrm{T}$ cell hybridomas reflecting $T_{\text {prod }}$ and $T_{\text {acc }}$.

This work was supported by a Grant-in-Aid for Scientific Research from the Ministry of Education, Science and Culture and the Ministry of Health and Welfare, Japan. We thank S. Enomoto, I. Yoshimatsu, R. Araki and T. Ikewaki for technical and secretarial assistance and B. T. Quinn for comments on the manuscript.

Received for publication 10 February 1989; and in revised form 12 April 1989

\section{REFERENCES}

1. Askenase P. W., Rosenstein R. W. and Ptak W. (1983) $\mathrm{T}$ cells produce an antigen-binding factor with in vivo activity analogous to IgE antibody. J. Exp. Med. 157, 862-873

2. Cher D. J. and Mosmann T. R. (1987) Two types of murine helper T cell clone. II. Delayedtype hypersensitivity is mediated by $\mathrm{T}_{\mathrm{H}} 1$ clones. J. Immunol. 138, 3688-3694

3. Cherwinski H. M., Schumacher J. H., Brown K. D. and Mosmann T. R. (1987) Two types of mouse helper $\mathrm{T}$ cell clone. III. Further differences in lymphokine synthesis between Thl and Th2 clones revealed by RNA hybridization, functionally monospecific bioassays, and monoclonal antibodies. J. Exp. Med. 166, 12291244
4. Colizzi V., Asherson G. L., James B. M. B. and Malkovsky M. (1984) T helper factor in contact sensitivity: antigen-specific I- $\mathrm{A}^{+}$helper factor is made by an Lyt-1 $1^{+} 2^{-}, \mathrm{I}-\mathrm{A}^{+}, \mathrm{I}-\mathrm{J}^{-} \mathrm{T}$ cell. Immunology 52, 261-267

5. Colizzi V., Asherson G. L., Zembala M. and JAMES B, M. B. (1985) I-A region genetic restriction in the production and action of an antigenspecific T-helper factor which bears I-A region determinant(s). Cell. Immunol. 95, 322-329

6. Himeno K., Yamada A., Miyata H., Nanishi F. and Noмото K. (1985) Antigen-specific augmentation of delayed-type hypersensitivity by immune serum factor in mice. Cell. Immunol. 95, 35-45

7. Imperiale M. J., Faherty D. A., Sproviero J. F. and Zauderer M. (1982) Functionally distinct helper $\mathrm{T}$ cells enriched under different culture conditions cooperate with different $B$ cells. J. Immunol. 129, 1843-1848

8. Kawauchi H., Shimamoto Y., Taniguchi K., Kuвo C. and Nомото K. (1982) Differences in thymus dependency among the alloreactive $\mathrm{T}$ cell subpopulations in their development. Cell. Immunol. 70, 76-84

9. Kawauchi H., Taniguchi K., Kato M., Shimaмото Y., Kuво C. and Noмото K. (1983) Differences in thymus dependency among the alloreactive $\mathrm{T}$-cell subpopulations in their development: Graft-versus-host reaction appears to be mediated by delayed-type hypersensitivity of tuberculin type. Cell. Immunol. 81, 403-412

10. Kawauchi H., Taniguchi K., Kubo C., Shimaмото Y. and Noмото K. (1983) The mechanism of reduction of cell-mediated cytotoxicity in neonatally thymectomized mice. Immunology 50, 199-205

11. Kim J., Woods A., Becker-Dunn E. and BotтомLY K. (1985) Distinct functional phenotypes of cloned Ia-restricted helper T cells. $J$. Exp. Med. 162, 188-201

12. Kubo C., Nomoto K., Taniguchi K., Nanishi F., Shimamoto Y. and TaKeya K. (1979) Direct cytotoxicity against chicken erythrocytes in mice. III. Degrees of radiosensitivity and crossreactivity of cytotoxicity, delayed hypersensitivity and antibody production. Immunology 37, 827-834

13. Kubo R. T. and Pelanne M. L. (1982) Tunicamycin inhibits the expression of membrane IgM in the human lymphoblastoid cell line. Daudi. Molec. Immunol. 20, 67-76

14. Kurt-Jones E. A., Hamberg S., Ohara J., Paul W. E. and ABBAS A. K. (1987) Heterogeneity of helper/inducer T lymphocytes. I. Lymphokine production and lymphokine responsiveness. $J$. Exp. Med. 166, 1774-1787

15. Little J. A., Asherson G. L., Colizzi V., James 
B. M. B. and Hraba T. (1985) Two-chain disulphide-bonded structure of antigen-specific $\mathrm{T}$ helper factor: both chains are necessary for activity and their interaction is I-A restricted. Immunology 55, 713-719

16. Melchers I., Fey K. and Eichmann K. (1982) Quantitative studies on $\mathrm{T}$ cell diversity. III. Limiting dilution analysis of precursor cells for $\mathrm{T}$ helper cells reactive to xenogeneic erythrocytes. J. Exp. Med. 156, 1587-1603

17. Mosmann T. R., Cherwinski H., Bond M. W. Giedlin M. A. and Coffman R. L. (1986) Two types of murine helper $\mathrm{T}$ cell clone. I. Definition according to profiles of lymphokine activities and secreted proteins. J. Immunol. 136, 2348-2357

18. Nakamura S., Himeno K., Yamada A., KawaMURA I. and Nomoto K. (1987) Antigen-specific augmentation factor involved in murine delayed-type footpad reaction. IV. Effect of delayed-type hypersensitivity augmentation factor on in vitro induction of DTH. Cell. Immunol. 105, 54-64

19. Nakamura S., Himeno K., Yamada A., Mitani M. and Nomoтo K. (1986) Antigen-specific augmentation of delayed-type hypersensitivity by immune serum factor in mice: Augmentation of anti-tumor cytostatic activity. Cell. Immunol. 103, 311-325

20. Nomoto K., Shimamoto Y., Taniguchi K., Kubo C., Kawauchi H., Mitsuyama M. and TAKeYA K. (1983) Development of immunity against Listeria monocytogenes in athymic nude versus neonatally thymectomized mice. Cell. Immunol. 75, 134-143

21. Nomoto, K., Taniguchi K., Kubo C. and TAKEYA K. (1978) Relationships among differentiated T-cell subpopulations. III. Radioresistance of delayed hypersensitivity to heterologous erythrocytes. Immunology 34, 517-521

22. Ptak W., Askenase P. W., Rosenstein R. W. and Gershon R. K. (1982) Transfer of an antigenspecific immediate hypersensitivity-like reaction with an antigen-binding factor produced by T cells. Proc. Natl. Acad. Sci. USA 79, 1969 1973

23. Sakumoto M., Himeno K., Kawamura I., Kishihara K., Matsuzaki G., Yoshikai Y. and Nomoto K. (1989) Early development of T cell subset responsible for delayed-type hypersensitivity after syngeneic bone marrow transplantation. Transplant. Proc. (in press)

24. Shimamoto Y., Kubo C., Taniguchi K. and Nomoто K. (1981) Difference in thymus dependency between effector and suppressor $\mathrm{T}$ cells for delayed footpad reaction to sheep erythrocytes in mice. Cell. Immunol. 61, 190-199

25. Shimamoto Y., Taniguchi K., Kubo C. and Nomoto K. (1980) Differences in thymusdependency among various $\mathrm{T}$-cell functions. Immunology 41, 167-178

26. Shin T, Mayumi H, Himeno K., Sanui H. and Nomoto K. (1984) Drug-induced tolerance to allografts in mice. I. Difference between tumor and skin grafts. Transplantation 37, 580-584

27. Swierkosz J. E., Marrack P. and Kappler J. W. (1979) Functional analysis of T cells expressing Ia antigens. I. Demonstration of helper T-cell heterogeneity. J. Exp. Med. 150, 1293-1309

28. TAda T., TAkemori T., Okumura K, Nonaka M. and TokuHISA T. (1978) Two distinct types of helper $T$ cells involved in the secondary antibody response: Independent and synergistic effects of $\mathrm{Ia}^{-}$and $\mathrm{Ia}^{+}$helper T cells. J. Exp. Med. 147, 446-458

29. Terasaka R., Nomoto K., Himeno K. and TAKEYA T. (1979) Relationships among differentiated T-cell subpopulations. IV. Preferential induction of delayed footpad reaction to xenografts and its radioresistant nature. Immunology 36, 699-705

30. Tucker M. J. and Bretscher P. A. (1982) T cells cooperating in the induction of delayedtype hypersensitivity act via the linked recognition of antigenic determinants. J. Exp. Med. 155, 1037-1049

31. Yamada A., Himeno K., Kumazawa Y. and Nомото K. (1984) Antigen-specific augmentation of delayed-type hypersensitivity by a humoral factor in the culture supernatant of immune spleen cells. Cell. Immunol. 84, 206209

32. Yamada A., Himeno K., Miyata H., KumaZAwA Y. and Nomoto K. (1984) Antigen-specific augmentation factor involved in murine delayed-type footpad reaction. I. Nature of augmentation factor. Cell. Immunol. 88, 184-192

33. Yamada A., Himeno K., NaKamura S., KawaMURA I. and Nomoto K. (1987) Transfer of resistance to primary infection of Listeria monocytogenes and early induction of delayed hypersensitivity by sera from $L$. monocytogenes-infected mice. Infec. Immunity 55, 30783084

34. Yamada A., Himeno K, Nakamura S. and Nomoto K. (1987) Antigen-specific augmentation factor involved in murine delayed-type footpad reaction. III. Genetic restriction of delayed hypersensitivity augmentation factor (DAF). Immunobiology 176, 24-34 